RESEARCH ARTICLE

\title{
A new record of Equus (Mammalia: Equidae) from the Late Pleistocene of central-south Chile
}

\author{
Un nuevo registro de Equus (Mammalia: Equidae) para el \\ Pleistoceno Superior de Osorno, Chile
}

OMAR P. RECABARREN ${ }^{1},{ }^{*}$, MARIO PINO$^{1} \&$ INÉS CID ${ }^{2}$

${ }^{1}$ Laboratorio de Paleoecología, Instituto de Ciencias Ambientales y Evolutivas, Universidad

Austral de Chile, Casilla 567, Valdivia, Chile

${ }^{2}$ Instituto de Ciencias Marinas y Limnológicas (ICML), Universidad

Austral de Chile, Casilla 567, Valdivia, Chile

*Corresponding author: orecabarren@gmail.com

\begin{abstract}
Fourteen dental and bone parts of a horse excavated from the Pilauco paleontological site, Osorno $\left(40^{\circ} 39^{\prime} \mathrm{S}^{\circ} 73^{\circ} 07^{\prime}\right.$ W) are analysed and interpreted. This site was formed in association with a peat bog located on the banks of the old Damas River and has conserved abundant late Pleistocene mammalian fauna and flora materials. A date of 11457 $\pm 14014 \mathrm{C}$ yrs B.P. was obtained from a molar and agrees with our stratigraphic age model. We have identified the fossils as pertaining to the species Equus (Amerhippus) andium, which confirms its presence in central-south Chile. Furthermore, the recorded geographic location indicate that the metapodial adaptations of the specimens previously described agree with the reconstructed late Pleistocene landscape of Pilauco, dominated by soft volcanic soils and isolated forest patches over large extensions of grasslands.
\end{abstract}

Key words: Equus, Equus (Amerhippus) andium, late Pleistocene, Pilauco.

\section{RESUMEN}

Se analizan e interpretan 14 fósiles correspondientes a dientes y huesos de caballo registrados en el sitio Pilauco,

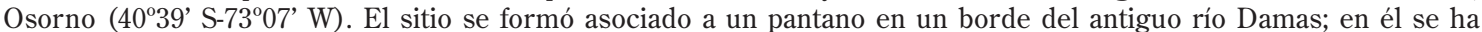
conservado abundante material de mastofauna y flora pleistocénica. Una fecha radiocarbónica de $11457 \pm 140$ A.P. obtenida de un molar, es concordante con el modelo de edad del sitio. La identificación taxonómica permite asociar a los fósiles a la especie Equus (Amerhippus) andium, lo que confirma la presencia de la especie en el centro-sur de Chile. Por otra parte, la posición geográfica de los hallazgos y la reconstrucción del paisaje indicarían que se trata de ejemplares cuyas adaptaciones en los metapodios son concordantes para el paisaje pleistocénico de Pilauco dominado por suelos volcánicos blandos, con presencia de bosquetes dispersos en grandes extensiones de praderas de gramíneas.

Palabras clave: Equus, Equus (Amerhippus) andium, late Pleistocene, Pilauco.

\section{INTRODUCTION}

Hippidiforms and equidiforms coexisted until the extinction of megafauna in the late Pleistocene around $10 \mathrm{ka}$ (kiloannun) (Orlando et al. 2003, Orlando et al. 2008, Orlando et al. 2009). Equids have been extensively studied in the northern hemisphere in relation to their evolutionary traits and paleoenvironment (MacFadden 1992). In South America, fossil horses are found in sediments from the late Pliocene to the late Pleistocene (Prado et al. 1998, Alberdi \& Prado 2004, Cerdeño et al. 2008). The most common and prominent feature of South American horses is their relatively large skull when compared to their respective body size (Alberdi \& Prado 2004, Alberdi et al. 2006). They are all grouped in the family Equidae Gray, 1821 and are divided in two genera; Hippidion Owen, 1869, endemic to South America (Alberdi \& Prado 1993, Prado \& Alberdi 1996, Alberdi \& Prado 1998) and Equus Linné, 1758, which includes the subgenus Equus (Amerhippus) sp. Hoffstetter, 1950, 
described for Chile in the late Pleistocene from $31^{\circ}$ to $39^{\circ} \mathrm{S}$ (Tamayo \& Frassinetti 1980 , Alberdi \& Frassinetti 2000, Alberdi \& Prado 2004).

This study presents the descriptions and taxonomic analyses of six teeth, a scapula fragment, one phalanx, one coxal, a pelvis fragment and a diaphysis from an unspecified long bone from the Pilauco site $\left(40^{\circ} 39^{\prime}\right.$ S- $73^{\circ} 07^{\prime}$ W) located in the city of Osorno, Los Lagos Region, Chile.

\section{METHODS}

\section{The Pilauco site}

The Pilauco site was discovered in 1986 and is located near the Damas River currently within the urban sprawl of Osorno (Fig. 1). It was discovered by workers who accidentally uncovered several skeletal remains of a gomphothere. Twenty years later the material was reanalyzed and the site re-excavated and studied since 2007 to date.

The fieldwork uncovered nine sediment layers. The PB-1 to PB-6 layers are composed by volcanoclastic and terrigenous sediments, which form a hill deposited between the Valdivia interglacial (Latorre et al. 2007) and the beginning of the Llanquihue glaciation (Mercer 1976). Above these layers and in the south facing slope the PB-7 and PB-8 layers are located, composed by peat and gravel clasts dispersed in the matrix. Both layers intercalate to the south to gravel sediments interpreted as fluvial deposits (Fig. 1). The fossils of mammalian fauna, birds, plants, diatoms and insects, among others, are associated to the PB-7 layer, dated between 12540 \pm 90 and $11122 \pm 17814 \mathrm{C}$ yrs B.P. (Fig. 2 and Table 1 ). The site stratigraphy is overlain by a layer of peat (PB9 ). The peats were deposited in an ox-bow lake which then became a peat-bog, in a former channel of the old Damas River, after the fluvial erosion of the south side of the Pleistocene volcaniclastic and detrital sediments that conformed the northern raised area (Pino \& Miralles 2008).

The analyzed fossils are deposited in the Museo Historico Municipal de Osorno and in the Pilauco site collection of the Laboratorio de Paleoecología, Instituto de Ciencias Ambientales y Evolutivas at Universidad Austral de Chile. The fossils are the following dental remains and elements of the appendicular skeleton: complete incisives MHMOP/PI/65, MHMOP/PI/69, MHMOP/PI/71; complete upper molar MHMOP/PI/66; upper molar fragment MHMOP/PI/67; complete lower molar MHMOP/PI/63; scapula fragment MHMOP/ $\mathrm{PI} / 544$; first phalanx MHMOP/PI/520; portion of the pelvis MHMOP/PI/21 (Fig. 3); fragments of upper molar buccal border MHMOP/PI/62, MHMOP/PI/68, MHMOP/PI/70, MHMOP/PI/541; and undetermined long bone diaphysis MHMOP/PI/60. All the material was collected in the 2007-2008 season, except for the coxal excavated in 1986. The grid and level (measured in relation to a local point of $10 \mathrm{~m}$ elevation) in which these fossils where found are shown in Fig. 4 and Table 2. The comparative study was developed with fossils of Hippidium principale, Equus (Amerhippus) neogeus and Equus (Amerhippus) sp. These fossils are deposited in the collections of the Museo de La Plata and Museo
Argentino de Ciencias Naturales "Bernardino Rivadavia" in Buenos Aires. In addition, Equus caballus skeletons from the Instituto de Anatomía Veterinaria of the Universidad Austral de Chile collection were used to support the morphological identification. Furthermore, the measurements proposed in the 1981 Hipparion Conference (Eisenmann et al. 1988) and the descriptions by Alberdi \& Frassinetti (2000) were also used for diagnosing the material.

The radiocarbon date reported in this study was obtained form a molar fragment of the PB-7 layer, grid $7 \mathrm{G}$, local height of $4.46 \mathrm{~m}$, and carried out by the NSFArizona AMS Laboratory, Arizona University, USA (AA1810) (Table 1).

\section{RESULTS}

Systematics

Class Mammalia Linneo, 1758

Order Perissodactyla Owen, 1848

Family Equidae Gray, 1821

Subfamily Equinae Gray, 1821

Genus Equus Linneo, 1758

Subgenus Amerhippus Hoffstetter, 1950

Einsenmann \& Turlot (1978) have described the systematics of the genus Equus. Within this genus, Alberdi \& Frassinetti (2000), Alberdi \& Prado (2004), and Rincón et al. (2006) describe in detail the species Equus (Amerhippus) sp. Among the different species assigned to this subgenus only Equus (Amerhippus) andium Branco, 1883 ex Wagner, 1860 has been described for Chile. The diagnosis done by Alberdi \& Prado (2004) describes this horse as having similar morphological characteristics to the subgenus, standing out for its small size in relation to other species of the group and its wider ocular orbit located more laterally and in a lower position. The appendicular skeleton features short and robust limbs, represented mainly by the radius and metapodials.

\section{Description of the material}

Of the six molars collected in this study, only three can be diagnosed analytically since the rest are fragments, which lack specific structures for aiding their determination. The first piece is the upper right molar (MHMOP/PI/66) corresponds to an M1-2 with narrow styles and without a groove in style. In the occlusal surface it is possible to observe a well defined pli caballinid, and the triangular protocone, longer in its distal than its mesial portion and joined to the 
(A)

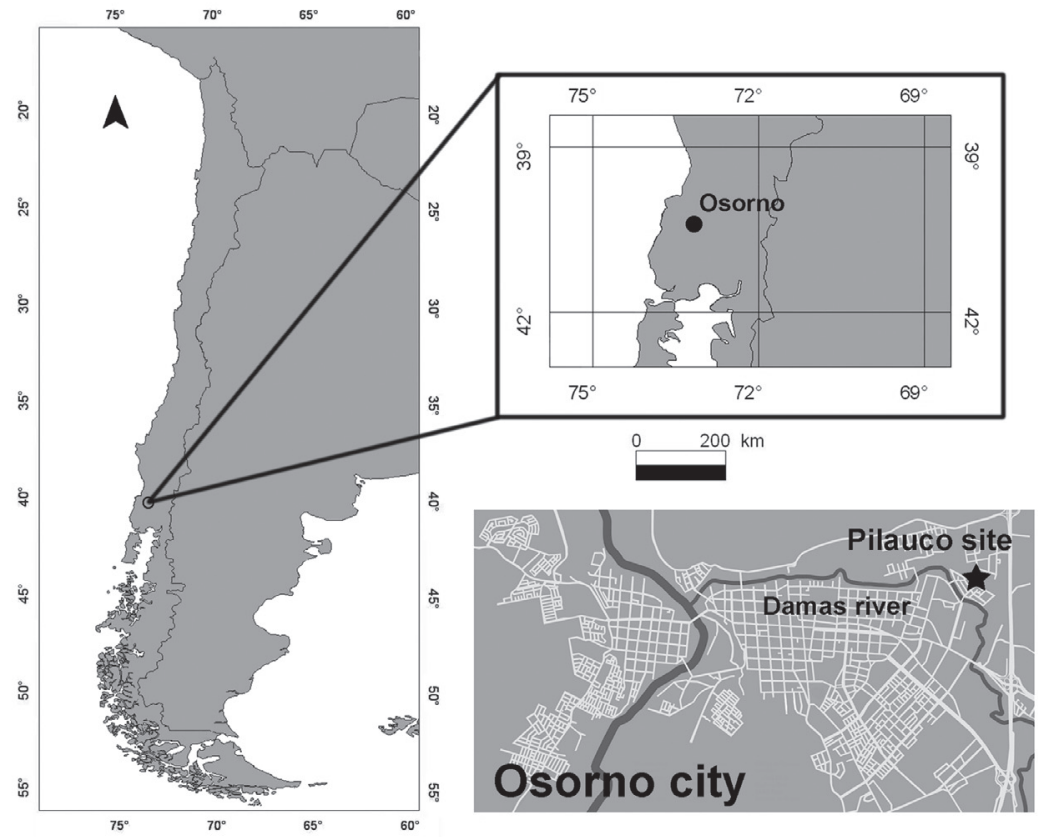

(B)

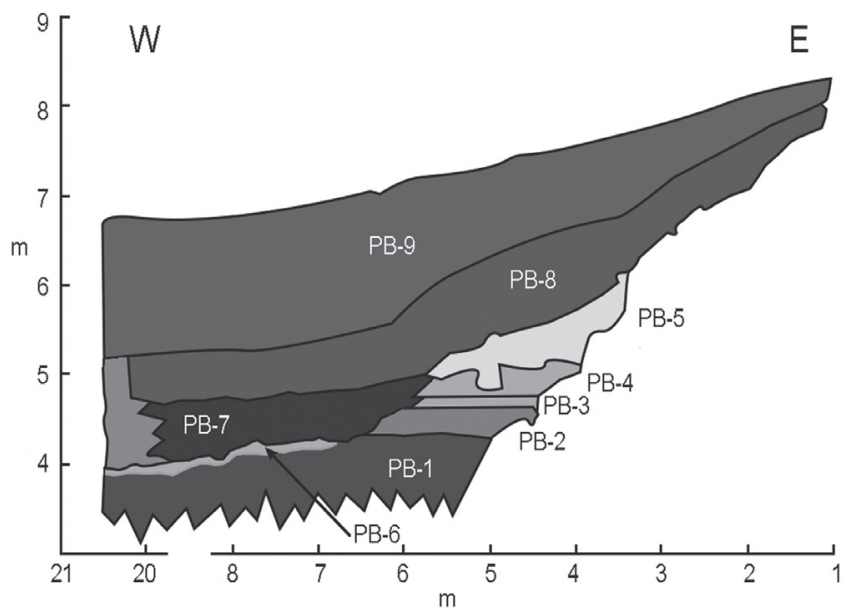

Fig. 1: (A) Location of the Pilauco site; (B) Schematic stratigraphy of the Pilauco site. PB-1: Lapilli tuff. PB-2: Lapilli tuff with abundant volcanic ash matrix. PB-3: Lapilli tuff with medium sand matrix. PB-4: Volcanic ash. PB-5: Terrigenous coarse sand, with scattered angular pebbles. PB-6: Gravel composed by clasts ranging from 1 to 15 $\mathrm{cm}$ in diameter. PB-7: Peat with very dark brown matrix (10YR 3/1) including isolated gravel clast of Andean source up to $7 \mathrm{~cm}$, poorly selected. Rest with erosion unconformity over PB-2 y PB-6. It contains the bones of extinct megamammals and extant mammals, plus countless plant and invertebrate remains. PB-8: Peat very similar to PB-7, but slightly more Brown in color (2.5Y 4/2). PB-9: Black peat (2.5 Y 2/0).

(A) Ubicación del sitio Pilauco; (B) Esquema estratigráfico del sitio Pilauco. PB-1: Toba de lapilli. PB-2: Toba de lapilli con abundante matriz de ceniza volcánica. PB-3: Toba de lapilli con matriz de arena media. PB-4: Ceniza volcánica. PB-5: Arena gruesa terrígena, con guijarros angulosos dispersos. PB-6: Grava compuesta por clastos de 1 a $15 \mathrm{~cm}$ de diámetro. PB-7: Turba de matriz marrón muy oscuro (10YR 3/1) con clastos aislados de origen andino de hasta $7 \mathrm{~cm}$, muy mal seleccionados. Se apoya con discordancia erosiva sobre PB-2 y PB-6. Contiene los huesos de la megamamíferos extintos y de los micromamíferos extantes; además innumerables restos vegetales y de invertebrados. PB-8: Turba de composición muy similar a PB-7, pero de color levemente más marrón (2.5Y 4/2). PB-9: Turba de color negro (2.5 Y 2/0). 
protoloph. The second piece is the upper left molar (MHMOP/PI/67), corresponds to an P3-4 by the width in their styles. It is also possible to observe the pli caballinid, with a triangular protocone, shorter in its distal portion than the first molar and also joined to the protoloph. The third piece is a lower left molar (MHMOP/PI/63). It is difficult to assign this piece to a position, nevertheless the open angle of the linguaflexid is in accordance with an m1-2. Its protostylid joins the protoconid and there is a well marked pli caballinid. The ectoflexid is deep but not enough to connect with the linguaflexid. It has a double knot formed by a rounded metaconid and a sharp metastylid, which is typical of Equus (Amerhippus). The dimensions of the above described molars are presented in Table 3.

The three incisives are significantly worn out due to natural use by the animal. The incisives MHMOP/PI/65 and MHMOP/PI/71 show dental pulp in their occlusal surface forming a structure with a triangular shape, which at this level is commonly known as dental star.

A right scapula was recovered from the

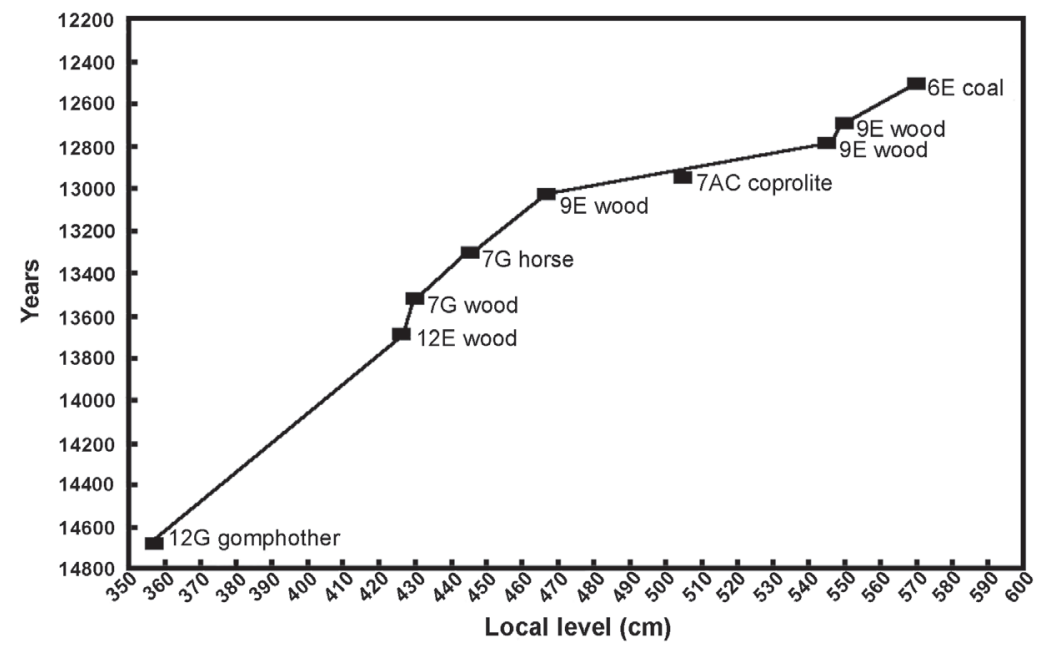

Fig. 2: Distribution of radiocarbon ages on the Pilauco site with respect to the measured depth relative to the local height of $10 \mathrm{~m}$ (calendar years, CalPal 2007). Type of dated materials and excavation units are indicated.

Distribución de las edades radiocarbónicas en el sitio Pilauco con respecto a la profundidad medida en relación a la cota local de $10 \mathrm{~m}$ (en años calendario, CalPal 2007). Se indican los materiales fechados y las cuadrículas de donde provienen.

TABLE 1

Three radiocarbon dates presented in this study. Radiocarbon dates were converted to "calendar" years (Median. prob. Age) using the Calib 5.0 program (Stuiver \& Becker 1993).

Tres fechas radiocarbónicas presentadas en este estudio. Las fechas radiocarbónicas fueron convertidas en años “calendario" usando el programa Calib 5.0 (Stuiver \& Becker 1993).

\begin{tabular}{lcc}
\hline${ }^{14} \mathrm{C}$ yr B.P. $\pm 1 \sigma$ error & Cal yr B.P. $1 \sigma$ ranges & Median. prob. age \\
\hline $11122 \pm 178$ & $12790-13170$ & 13045 \\
$11457 \pm 140$ & $13173-13438$ & 13321 \\
$12540 \pm 90$ & $14519-15040$ & 14680 \\
\hline
\end{tabular}




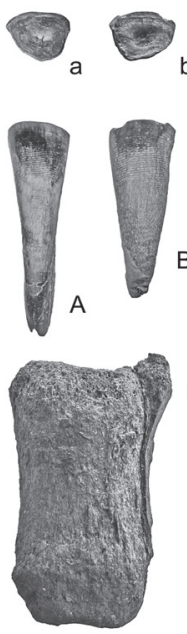

g1
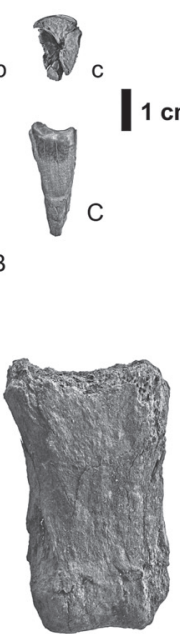

g2

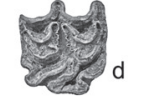

$\mathrm{cm}$

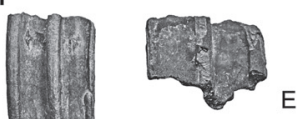

D

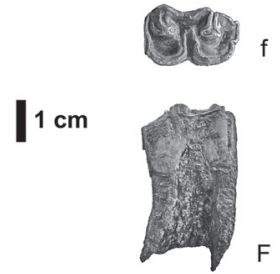

F

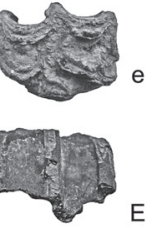

TABLE 2

Fossil depths used in this study, measured in relation to a local point of $10 \mathrm{~m}$ elevation.

Profundidades de los fósiles utilizados en este estudio. Las medidas fueron hechas desde un punto local de cota $10 \mathrm{~m}$.

\begin{tabular}{lc}
\hline Code & Depths \\
\hline MHMOP/PI/69 & 1.50 \\
MHMOP/PI/60 & 4.25 \\
MHMOP/PI/63 & 4.30 \\
MHMOP/PI/68 & 3.85 \\
MHMOP/PI/541 & 4.36 \\
MHMOP/PI/520 & 4.30 \\
MHMOP/PI/62 & 4.09 \\
MHMOP/PI/67 & 4.46 \\
MHMOP/PI/544 & 4.22 \\
MHMOP/PI/71 & 4.33 \\
MHMOP/PI/65 & - \\
MHMOP/PI/66 & 3.81 \\
MHMOP/PI/70 & - \\
\hline
\end{tabular}

\section{N}

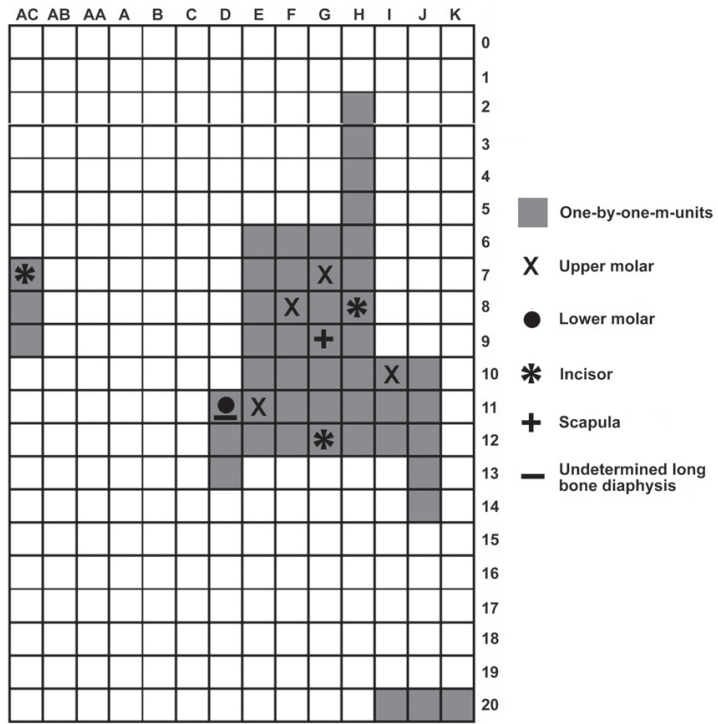

Fig. 4: Pilauco site excavation map, modified from Pino \& Miralles (2008). The grid shows the distribution of the one-by-one $\mathrm{m}$ units in which horse fossils were found. Units 20I, 20J, 20K, 7AC, 8 AC y $9 A C$ mark the limits of the Pleistocene swamp formed on the banks of the Damas River.

Mapa de la excavación del sitio Pilauco, modificado de Pino y Miralles (2008). Se aprecia la distribución de cuadrículas en las cuales fueron encontrados fósiles de caballo. Las cuadrículas 20I, 20J, 20K, 7AC, $8 \mathrm{AC}$ y $9 \mathrm{AC}$ marcan los límites del pantano pleistocénico, a orillas del antiguo río Damas. 
TABLE 3

Measurements taken for the scapula (MHMOP/PI/544), right portion of the pelvis (MHMOP/ $\mathrm{PI} / 21$ ), the first phalanx (MHMOP/PI/50), upper molars (MHMOP/PI/66; MHMOP/PI/67), lower molar (MHMOP/PI/63) according to the Hipparion Conference (Eisenmann et al. 1988). The ac letters indicate the approximate value of the measure. All measurements are in millimetres.

Medidas tomadas a la escápula (MHMOP/PI/54), la primera falange (MHMOP/PI/50), molares superiores (MHMOP/PI/66; MHMOP/PI/67), molar inferior (MHMOP/PI/63) según la Hipparion Conference (Eisenmann et al. 1988). Las letras ac indican un valor aproximado de la medida. Las dimensiones se expresan en milímetros.

\begin{tabular}{lcccccccccc}
\hline Code & Fossil & 1 & 2 & 3 & 4 & 5 & 6 & 7 & 8 & 9 \\
\hline MHMOP/PI/544 & Scapula & $187 \mathrm{ac}$ & $52 \mathrm{ac}$ & 62 & 47 & 48 & $24 \mathrm{ac}$ & - & - & - \\
MHMOP/PI/21 & Right portion of the pelvis & 74.6 & - & - & - & - & - & - & - & - \\
MHMOP/PI/50 & First phalanx & 70 & 65 & 33 & 42 & 26 & 34 & 27 & 15 & 37 \\
MHMOP/PI/66 & M1-2 & 43.7 & 20.7 & 9.9 & 22.5 & - & - & - & - & - \\
MHMOP/PI/67 & P3-4 & - & 31.6 & 8.4 & 23.2 & - & - & - & - & - \\
MHMOP/PI/63 & m1-2 & 18.6 & 20.8 & 5.3 & 13 & 4.6 & 12.4 & - & - & - \\
\hline
\end{tabular}

appendicular skeleton, which presents a posterior rim with parts of the distal spine and a complete glenoid cavity (Table 3 ). The first phalanx have clear signs of wear by transport, but shows the $\mathrm{V}$ shaped trigonum falangis, characteristic of Equus (Amerhippus). Although the spatial pattern of the fossils is highly dispersed (Fig. 4), the absence of repeated pieces does not insure the presence of more than one specimen. The worn out upper and lower molars and incisives indicate an adult stage of the specimen.

According to the above description and based on the dentition and first phalanx, the remains found in the Pilauco site can be classified as Equus (Amerhippus) sp. The $11457 \pm 140$ yrs B.P. radiocarbon dating places the fossil in the late Pleistocene and is in accordance with the other dates of the site.

\section{DISCUSSION}

Despite the low numbers of horse fossils in the Pilauco site they can all be related to the descriptions done for Equus (Amerhippus) sp. (i.e. Alberdi \& Prado 2004). For this subgroup, the southernmost record in Chile is in the locality of Huimpil $38^{\circ} \mathrm{S}$, identified through a left M3 without a stratigraphic context (Alberdi $\&$ Frassinetti 2000).

In South America the most southern distribution of the genus Equus (Equus (Amerhippus) neogeus; Alberdi \& Prado 2004), has been recorded at $39^{\circ} \mathrm{S}$ in the pampean region of Argentina. This report expands the geographic distribution of the genus Equus to $40^{\circ} \mathrm{S}$.

The lack of horse metapodials and skulls from Pilauco prevents any discussion regarding of morphological similarities or differences with the previously described species north of $40^{\circ} \mathrm{S}$, e.g., E. (Amerhippus) andium and $E$. (Amerhippus) neogeus. The latter has been described as the largest species, with long and robust appendicular bones, standing out for its slenderness within the subgenus that inhabited the pampean region (Alberdi \& Prado 2004, Prado \& Alberdi 2008). Moreover, Equus (Amerhippus) andium is a smaller sized species, with short metapodial morphology especially adapted to mountain habitats (Prado \& Alberdi 1994), being similar to Hippidion saldiasi. This species has short and wide limbs adapted to rocky and irregular surfaces and possibly to frozen areas (Paunero et al. 2008). According to Alberdi \& Prado (2004), the Hippidion and Equus metapodials differ according to soil type. Hard and calcareous soils of the pampean region would be related to the above described bones of $E$. (Amerhippus) neogeus, whereas the transversally wider metapodials described for E. (Amerhippus) andium would be better adapted to soft soils 
such as the Andisols (Soil Survey Staff 2003) of southern Chile.

At the end of the Pleistocene, the dominant landscapes of central-south Chile were temperate rainforests dominated by Nothofagus and conifers, which survived at low elevation sites (such as Pilauco) with their populations reduced to areas between $40^{\circ}$ and $42^{\circ} \mathrm{S}$ (Villagrán 1991, Villagrán 2001, Solari 2007). Based on pollen analyses, Abarzúa \& GajardoPinchicura (2008) describe the dominant families species of Pilauco between 11800 and $1115014 \mathrm{C}$ yrs B.P. such as Poaceae and Asteraceae, forming an open landscape similar to a park. This analysis also revealed the presence of patches of conifer forests with species such as lleuque (Prumnopitys andina), mañío (Podocarpus nubigenus and Saxegothaea conspicua) and ciprés de las Guaitecas/alerce (Fitzroya/Pilgerodendron). A variety of Myrtaceae, coiguies (Nothofagus similar to dombeyi), maitén (Maytenus sp.), olivillo (Aextoxicon punctatum), as well as ferns and aquatic plant species were also present at that time. This environment appears to be more related with the morphological adaptations described for $E$. (Amerhippus) andium. As Alberdi \& Frassinetti (2000) mention, this variety of horses could have migrated from Ecuador through the Andes mountains down to central-south Chile, where they found an appropriate environment to live.

In conclusion, the current state of genetic studies for the genus Equus in addition to morphological comparisons with fossils, support the attribution of the Pilauco horse fossil (specifically the molars and first phalanx) to the subgenus Equus (Amerhippus) sp., based on the arguments given above, we propose that this fossil belongs to the the species Equus (Amerhippus) andium. This finding makes it the southernmost record of this horse from the late Pleistocene (Lujanian).

ACKNOWLEDGEMENTS: We gratefully acknowledge the support of grants Fondecyt (1100555) and FNDR Región de Los Lagos (2308-56-LE07). We also thank Fredy Carlini from the Museo de La Plata and Alejandro Kramarz from the Museo Argentino de Ciencias Naturales "Bernardino Rivadavia" of Buenos Aires for allowing us to review the collections. To Claudio Latorre, María Teresa Alberdi, and one anonymous reviewer for helpful comments and suggestions. Many thanks to Marcelo Gómez and Pedro Aburto from the Instituto de Anatomía Veterinaria of the UACh, for their invaluable help.

\section{LITERATURE CITED}

ABARZÚA A \& A GAJARDO-PINCHICURA (2008) ¿Y qué nos cuentan los polen?: La historia climática y vegetacional del sitio Pilauco. In: Pino M (ed) Pilauco: Un sitio complejo del Pleistoceno tardío. Osorno, Norpatagonia chilena: 49-54. Láminas: 143-145. Imprenta América, Valdivia, Chile.

ALBERDI MT \& JL PRADO (1993) Review of the genus Hippidion Owen, 1869 (Mammalia: Perissodactyla) from the Pleistocene of South America. Zoological Journal of the Linnean Society 108: 1-22.

ALBERDI MT \& JL PRADO (1998) Comments on: Pleistocene horses from Tarija, Bolivia, and validity of the genus Onohippidium (Mammalia: Equidae), by B. J. MacFadden. Journal of Vertebrate Paleontology 3: 669-672.

ALBERDI MT \& D FRASSINETTI (2000) Presencia de Hippidion y Equus (Amerhippus) (Mammalia, Perissodactyla) y su distribución en el Pleistoceno Superior de Chile. Estudios Geológicos 56: 279290.

ALBERDI MT \& JL PRADO (eds) (2004) Los caballos fósiles de América del Sur. Una historia de 3 millones de años. INCUAPA Serie monográfica, Universidad Nacional del Centro de la Provincia de Buenos Aires, Argentina 3: 1-269.

ALBERDI MT, JL PRADO \& CM FAVIER-DUBOIS (2006) Nuevo registro de Hippidion principale (Mammalia, Perissodactyla) del Pleistoceno de Mar del Sur, Argentina. Revista Española de Paleontología 2: 105-113.

CALPAL (2007) Cologne radiocarbon calibration \& paleoclimate research package. URL: http://www. calpal-online.de/ (accessed December 22, 2010).

CERDEÑO E, S MOREIRAS \& MT ALBERDI (2008) Primeros hallazgos del équido Hippidion (Perissodactyla) en el Pleistoceno de la provincia de Mendoza, Argentina. Revista del Museo Argentino de Ciencias Naturales 2: 211-220.

EISENMANN V, MT ALBERDI, C DE GIULI \& U STAESCHE (1988) Collected papers after the "New York International Hipparion Conference, 1981”. In: Woodbrune M \& P Sondaar (eds) Studying fossil horses, 1, Methodology: 1-72. EJ Brill, Leiden, The Netherlands.

EISENMANN V \& JC TURLOT (1978) Sur la taxinomie du genre Equus. Les Cahiers de l' Analyse des Données 3: 179-201.

LATORRE C, P MORENO, G VARGAS, A MALDONADO, R VILLA-MARTÍNEZ et al. (2007) Quaternary environments and landscape evolution. In: Moreno T \& W Gibbons (eds) Geology of Chile: 309-328. London Geological Society Press. London.

MAcFADDEN BJ (1992) Fossil horses: Systematics, paleobiology, and evolution of the Family Equidae. Cambridge University Press, New York.

MERCER J (1976) Glacial history of southernmost South America. Quaternary Research 6: 125-166.

ORLANDO L, V EISENMANN, F REYNIER, P SONDAAR \& C HÄNNI (2003) Morphological convergence in Hippidion and Equus (Amerhippus) southern-american equids elucidated by ancient DNA analysis. Journal of Molecular Evolution 1: S29-S40.

ORLANDO L, D MALE, MT ALBERDI, JL PRADO, A PRIETO, A COOPER \& C HÄNNI (2008) Ancient DNA clarifies the evolutionary history 
of American Late Pleistocene Equids. Journal of Molecular Evolution 66: 533-538.

ORLANDO L, JL METCALF, MT ALBERDI, M TELLESANTUNES, D BONJEAN et al. (2009) Revising the recent evolutionary history of equids using ancient DNA. Proceedings of the National Academy of Science of the United States of America 106: 21754-21759.

PAUNERO RS, G ROSALES, JL PRADO \& MT ALBERDI (2008) Cerro Bombero: Registro de Hippidion saldiasi Roth, 1899 (Equidae, Perissodactyla) en el Holoceno temprano de Patagonia (Santa Cruz, Argentina). Estudios Geológicos 1: 89-98.

PINO M \& C MIRALLES (2008) La geología cuaternaria de Pilauco. In: Pino M (ed) Pilauco: Un sitio complejo del Pleistoceno tardío. Osorno, Norpatagonia chilena: 37-42. Láminas: 136-137. Imprenta América, Valdivia, Chile.

PRADO JL \& MT ALBERDI (1994) A quantitative review of the horse genus Equus from South America. Palaeontology 37: 459-481.

PRADO JL \& MT ALBERDI (1996) A cladistic analysis of the horses of the tribe Equini. Palaeontology 39: 663-680.

PRADO JL, MT ALBERDI \& MA REGUERO (1998) El registro más antiguo de Hippidion Owen, 1869 (Mammalia, Perissodactyla) en América del Sur. Estudios Geológicos 54: 85-91.

PRADO JL \& MT ALBERDI (2008) Restos de Hippidion y Equus (Amerhippus) procedentes de las barrancas de San Lorenzo, Pleistoceno tardío (provincia de Santa Fe, Argentina). Revista Española de Paleontología 2: 225-236.

RINCÓN AD, MT ALBERDI \& JL PRADO (2006) Nuevo registro de Equus (Amerhippus) santaeelenae (Mammalia, Perissodactyla) del pozo de asfalto de Inciarte (Pleistoceno Superior), estado Zulia, Venezuela. Ameghiniana 43: 529-538.

SOIL SURVEY STAFF (2003) Keys to soil taxonomy. Ninth edition. USDA-Natural Resources Conservation Service, Washington, DC.

SOLARI ME (2007) Historia ambiental holocénica de la región sur-austral de Chile (X-XII región). Revista Austral de Ciencias Sociales 13: 79-92.

STUIVER M \& B BECKER (1993) High-precision decadal calibration of the radiocarbon time scale, AD 1950-6000 BC. Radiocarbon 35: 35-65.

TAMAYO M \& D FRASSINETTI (1980) Catálogo de los mamíferos fósiles y vivientes de Chile. Boletín del Museo Nacional de Historia Natural Chile 37: $323-405$.

VILLAGRÁN C (1991) Historia de los bosques templados del sur de Chile durante el Tardiglacial y Postglacial. Revista Chilena de Historia Natural 64: 447-460.

VILLAGRÁN C (2001) Un modelo de la historia de la vegetación de la Cordillera de La Costa de Chile central-sur: La hipótesis glacial de Darwin. Revista Chilena de Historia Natural 74: 793-803. 